\title{
Minimizing Chloride Interferences Produced by Calcium Chloride in the Determination of Cd by Graphite Furnace Atomic Absorption Spectrometry
}

\author{
Christophe Waterlot ${ }^{1,2}$ and Francis Douay ${ }^{1,2}$ \\ ${ }^{1}$ Université Lille Nord de France, 59044 Lille, France \\ ${ }^{2}$ Groupe ISA, Equipe Sols et Environnement, Laboratoire Génie Civil et géo-Environnement (LGCgE), \\ Lille Nord de France, 48 boulevard Vauban, 59046 Lille Cedex, France \\ Correspondence should be addressed to Christophe Waterlot, christophe.waterlot@isa-lille.fr
}

Received 3 August 2012; Accepted 29 August 2012

Academic Editors: M. Mạczka, I. Narin, and T. Stafilov

Copyright ( $) 2012$ C. Waterlot and F. Douay. This is an open access article distributed under the Creative Commons Attribution License, which permits unrestricted use, distribution, and reproduction in any medium, provided the original work is properly cited.

\begin{abstract}
Cadmium concentrations in $\mathrm{CaCl}_{2}$ extracting solutions at various concentrations were determined by graphite furnace atomic absorption using two background correctors: the deuterium and the high-speed self-reversal background correction systems. Under- and overestimation of the $\mathrm{Cd}$ absorbance signals in $\mathrm{CaCl}_{2}$ solutions were observed for concentrations greater than $0.005 \mathrm{M}$ using the deuterium lamp while no important effect was observed using the other background correction system. The analytical performance of the spectrometer for the determination of $\mathrm{Cd}$ was studied in $0.01 \mathrm{M} \mathrm{CaCl}_{2}$ solution and single extractions were performed using reference materials and contaminated soil samples. Cadmium was determined using the two background correction systems and a third method, which consists of the use of the deuterium lamp without any chemical modifier, was added to the study. The results showed that the third method was unable to determine $\mathrm{Cd}$ concentrations in the $\mathrm{CaCl}_{2}$ solution due to the presence of extractable arsenic and iron. For solutions without any dilution or diluted with a very low dilution factor, the $\mathrm{CaCl}_{2}-$ extractable Cd concentrations measured using the deuterium lamp were systematically below those found using the high-speed self-reversal method. These differences were explained by the presence of chloride ions in the atomization step.
\end{abstract}

\section{Introduction}

Cadmium uptake by organisms is poorly related to the total Cd concentrations in contaminated soils [1]. Many studies pointed out that the chemical behavior and the potential toxicity of metals (often related to their environmental availability to organisms) depended on the binding of metals with ligands [2-6]. Depending on the physicochemical parameters of the soils, the soluble metals usually react with organic (humic and fulvic acids) as well as inorganic (sulfate, sulfide, phosphate, carbonate, oxide and hydroxide, and chloride) ligands. The most-studied ligand is probably the chloride ion because salinity increases Cd-uptake by plants by forming environmentally available Cd-chloro complexes as $\mathrm{CdCl}^{+}$and $\mathrm{CdCl}_{2}[5,7-13]$.
The prediction of metal bioavailability is of crucial importance for the assessment of environmental quality of contaminated soils. Thus, to understand the processes involved in metal uptake by plants (phytoavailability), the use of extracting solutions rather than the total metal contents is so recommended [13-16]. Among salt solutions used in single extractions, calcium chloride $\left(\mathrm{CaCl}_{2}\right)$ appears as the most widely used extractant to assess plant-available Cd concentrations in soils [15-18]. Compared to the other salts, $\mathrm{CaCl}_{2}$ does not interfere with the natural $\mathrm{pH}$ of the soil [19]. On the other hand, the $\mathrm{CaCl}_{2}$ extracting solution improves the metal desorption within the soils due to the complexation of free ions by $\mathrm{Cl}^{-}[19,20]$. Molar (M), decimolar, $0.05 \mathrm{M}$, and centimolar concentrations are widely used by various authors to study the metal behaviors and 
particularly to estimate the phytoavailable $\mathrm{Cd}$ in soils $[16,21$, 22]. However, high concentrations of $\mathrm{CaCl}_{2}$ produce many problems in terms of chemical analysis of $\mathrm{Cd}$ at trace levels using GFAAS. With this technique and at the most sensitive line for Cd (228.802 nm), spectral interferences have been reported for the use of ammonium phosphate as a chemical modifier, especially when determining very low concentrations of $\mathrm{Cd}$ in matrices with iron (Fe) and arsenic (As) contents and especially with high chloride concentrations, one of the main causes of background noise in GFAAS [23]. These interferences cannot be eliminated using the deuterium background correction $\left(\mathrm{D}_{2}-\mathrm{BGC}\right)$, or Zeemaneffect background correction system, but they can be minimized using palladium-magnesium, palladium-ammonium, ammonium salt of EDTA, nickel, or hydrofluoric acid as chemical modifiers [23-27].

In recent years, the high-speed self-reversal background correction (HSSR-BGC) system has been presented as a powerful background corrector to avoid background interferences between $\mathrm{Pb}$ and some anionic species $\left(\mathrm{SO}_{4}{ }^{2-}\right.$, $\mathrm{SiO}_{3}{ }^{-}, \mathrm{PO}_{4}{ }^{3-}$, and $\mathrm{NO}_{3}{ }^{-}$) [28] and spectral interferences between $\mathrm{Cd}$ and $\mathrm{As} / \mathrm{Fe}$ species $[29,30]$. Based on the Smith-Hieftje (S-H method) background corrector [31], the specificity of the HSSR-method is the high frequency applied during measurements which permits a rapid modulation between currents at low and high levels through the $\mathrm{Cd}$ hollow-cathode lamp. In this work, the development of an analytical method to measure $\mathrm{Cd}$ in $\mathrm{CaCl}_{2}$ extracting solution by GFAAS associated to the HSSR-BGC is presented and compared with the $\mathrm{D}_{2}$-BGC for which a deuterium lamp was used as a continuum light source in combination with a chemical modifier. The effects of $\mathrm{CaCl}_{2}$ on the $\mathrm{Cd}$ absorbance were carefully studied and optimized. The accuracy of the proposed method was verified by means of four reference materials. The analytical technique was successfully applied to the determination of $\mathrm{CaCl}_{2}$-extractable $\mathrm{Cd}$ in soils contaminated with various metals collected in the north of France.

\section{Materials and Methods}

2.1. Standard Solutions and Reagents. All $\mathrm{CaCl}_{2}$ solutions were prepared from calcium chloride dihydrate reagent for analysis (Acrōs Organics, Noisy-le-Grand, France) and doubly distilled water (Carlo Erba, Val de Reuil, France) with a specific conductivity of $0.1 \mu \mathrm{S} \mathrm{cm}^{-1}$. The $\mathrm{Cd}$ metal stock solutions, 1,2 , and $5 \mathrm{mg} \mathrm{L}^{-1}$ in $2 \% \mathrm{HNO}_{3}$ (Chemical Products for Analysis, Association Corporation Standard Distribution, C.P.A. groupe A.C.S.D., Voisins le Bretonneux, France), were used for the preparation of standard solutions.

All glassware and polypropylene materials were cleaned by soaking for 1 day in $0.5 \mathrm{M}$ nitric acid (J.T. Baker for metal trace analysis, Deventer, Netherlands), rinsed with doubly distilled water and stored in closed plastic bags.

2.2. Instrumentation. Measurements of $\mathrm{Cd}$ in $\mathrm{CaCl}_{2}$ extracting solutions were carried out by means of a Shimadzu Model AA-6800 atomic absorption spectrometer (GFAAS, Tokyo,
Japan) fitted with a digital control technology graphite furnace atomizer (GFA-EX7), an ASC-6100 autosampler, and an ASK-6100 autodiluter (Shimadzu, Tokyo, Japan). Pyrolytic graphite-coated tubes with pyrolytic L'vov platforms from Shimadzu were used throughout this work. Firstly, a conventional Cd hollow-cathode lamp (Hamamatsu, Photonics K.K., Tokyo, Japan) was used as the spectral radiation source at a $228.802 \mathrm{~nm}$ analytical line, and was operated at $10 \mathrm{~mA}$ in combination with a deuterium lamp for the background correction ( $\mathrm{D}_{2}$-BGC). A Cd high-intensity boosted discharge hollow-cathode lamp from Hamamatsu was also used. This lamp was operated with two different discharges within the lamp, a low-current value (10 $\mathrm{mA}$ ) and then, a high-current value $(300 \mathrm{~mA})$ in order to increase the emission intensity and was pulsed with a frequency of $100 \mathrm{~Hz}$ (HSSR-BGC). Both Cd lamps were used with spectral bandpass value of $1.0 \mathrm{~nm}$. The iron concentration in $\mathrm{CaCl}_{2}$ solutions was determined by flame atomic absorption spectrometer with an ASC-6100 autosampler (Shimadzu) at $248.3 \mathrm{~nm}$ with a lamp current of $12 \mathrm{~mA}$ and a deuterium lamp (Hamamatsu) for the background correction. Arsenic concentrations were measured by GFAAS following the procedure described by Oppermann et al. [29].

2.3. Soil Sampling and Pretreatment Procedure. The contaminated soils were collected in an area highly affected by the past atmospheric emissions of two lead and zinc smelters located in the north of France. For each site, a composite sample was constituted in the ploughed layer $(0-25 \mathrm{~cm})$ and was prepared following the NF ISO 11464 procedure. The samples were then sieved to less than $250-\mu \mathrm{m}$ particle size using an ultracentrifugal mill (Retsch type ZM 200, Hann, Germany) to obtain contaminated soil samples named CS1 to CS9 for subsequent analyses. Moreover, the validation of the proposed method was carried out using four reference materials:

(i) CRM BCR-483: certified reference material composed of sewage-sludge-amended soil from Great Billings Sewage Farm (Northampton, England) with indicative $\mathrm{CaCl}_{2}$-extractable $\mathrm{Cd}$.

(ii) CRM BCR-141R: certified reference material composed of calcareous loam soil.

(iii) CRM BCR-701: certified reference material composed of sediment from Lake Orta (Piemonte, Italy).

(iv) SRM 2710a (NIST): Standard reference material (Montana I soil) from Montana, USA.

2.4. Extraction Procedures. Triplicate subsamples of each soil and replicate six samples of reference materials were weighed $(3 \mathrm{~g})$ in a polyethylene tube and $30 \mathrm{~mL}$ of $0.01 \mathrm{M} \mathrm{CaCl}_{2}$ solution was added. After shaking the suspension with a rotor disc for $2 \mathrm{~h}$ at $10 \mathrm{rpm}$, the extract was separated from the solid residue by centrifugation at $4530 \mathrm{rpm}$ (Rotanta 460 Hettich, Tuttlingen, Germany) for $20 \mathrm{~min}$ at room temperature. Afterwards, the solution was filtered over an acetate Millipore membrane (Millipore, $0.45-\mu \mathrm{m}$ porosity, Minisart) and was transferred into a polypropylene container 


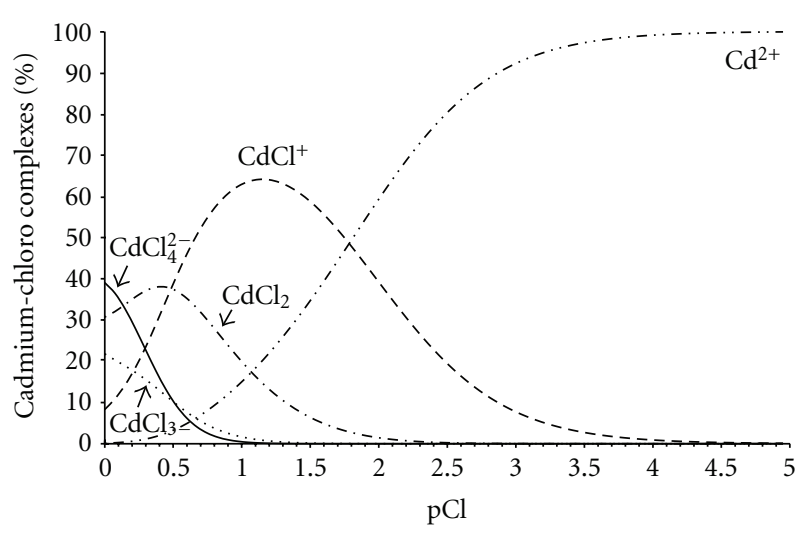

Figure 1: Distribution graph of Cd-chloro complexes.

[30]. The concentrations of $\mathrm{Cd}$ in the $0.01 \mathrm{M} \mathrm{CaCl}_{2}$ solutions were expressed as $\mu \mathrm{g} \mathrm{kg}^{-1}$ dry weight (DW).

2.5. Soil Moisture Content. The residual moisture contents were measured by weighing three replicates of each soil samples before and after drying at $105^{\circ} \mathrm{C}$ in an oven (Binder, Tuttlingen, Germany) until it reached a constant mass according to the NF ISO 11465 standard.

2.6. Statistical Analyses. For each soil, Bonferroni, a Tuckey, and Fischer post hoc tests were conducted to determine significant differences among $\mathrm{Cd}$ concentrations according to the analytical techniques and the background compensations. All statistical tests were performed using Statistica
6.0 (Statsoft, Tulsa, OK, USA) for Windows. The level of significance was set at $P<0.05$.

\section{Theory and Calculation}

Cadmium-free ions can react to chloride according to a molar ratio $\mathrm{Cd}: \mathrm{Cl}$ up to $1: 4$ to form the complex $\mathrm{CdCl}_{n}{ }^{2-n}$ $(0 \leq n \leq 4)$ [32]. The mechanism, stepwise, is described as follow:

$$
\begin{array}{cc}
\mathrm{Cd}^{2+}+\mathrm{Cl}^{-} \longrightarrow \mathrm{CdCl}^{+} & \log K f_{1}=1.98 \\
\mathrm{Cd}^{2+}+2 \mathrm{Cl}^{-} \longrightarrow \mathrm{CdCl}_{2} & \log K f_{2}=2.60 \\
\mathrm{Cd}^{2+}+3 \mathrm{Cl}^{-} \longrightarrow \mathrm{CdCl}_{3}{ }^{-} & \log \mathrm{Kf}_{3}=2.40 \\
\mathrm{Cd}^{2+}+4 \mathrm{Cl}^{-} \longrightarrow \mathrm{CdCl}_{4}{ }^{2-} & \log \mathrm{Kf}_{4}=2.50 .
\end{array}
$$

For each equation, equilibrium constant $\left(K f_{n}\right)$ is expressed as the following general equation:

$$
K f_{n}=\frac{\left[\mathrm{CdCl}_{n}^{2-n}\right]}{\left[\mathrm{Cd}^{2+}\right]\left[\mathrm{Cl}^{-}\right]^{n}}
$$

where $n$ is the number of $\mathrm{Cl}^{-}$added to the $\mathrm{Cd}^{2+}$ ion; $\mathrm{CdCl}_{n}{ }^{2-n}, \mathrm{Cd}^{2+}$ and $\mathrm{Cl}^{-}$are expressed in concentrations. The use of the principle of the matter conservation permitted to defined the total dissolved $\mathrm{Cd}\left([\mathrm{Cd}]_{T}\right)$ as the sum of the soluble Cd-chloro complexes. The concentration of each of them can be denoted by the three terms $[\mathrm{Cd}]_{T},\left[\mathrm{Cl}^{-}\right]$and $K f_{n}$ and expressed as follows.

$$
\begin{aligned}
{\left[\mathrm{Cd}^{2+}\right] } & =\frac{[\mathrm{Cd}]_{T}}{1+K f_{1}\left[\mathrm{Cl}^{-}\right]+K f_{2}\left[\mathrm{Cl}^{-}\right]^{2}+K f_{3}\left[\mathrm{Cl}^{-}\right]^{3}+K f_{4}\left[\mathrm{Cl}^{-}\right]^{4}}, \\
{\left[\mathrm{CdCl}^{+}\right] } & =\frac{K f_{1}[\mathrm{Cd}]_{T}}{K f_{1}+1 /\left[\mathrm{Cl}^{-}\right]+K f_{2}\left[\mathrm{Cl}^{-}\right]+K f_{3}\left[\mathrm{Cl}^{-}\right]^{2}+K f_{4}\left[\mathrm{Cl}^{-}\right]^{3}}, \\
{\left[\mathrm{CdCl}_{2}\right] } & =\frac{K f_{2}[\mathrm{Cd}]_{T}}{K f_{2}+1 /\left[\mathrm{Cl}^{-}\right]^{2}+K f_{1} /\left[\mathrm{Cl}^{-}\right]+K f_{3}\left[\mathrm{Cl}^{-}\right]+K f_{4}\left[\mathrm{Cl}^{-}\right]^{2}}, \\
{\left[\mathrm{CdCl}_{3}{ }^{-}\right] } & =\frac{K f_{3}[\mathrm{Cd}]_{T}}{K f_{3}+1 /\left[\mathrm{Cl}^{-}\right]^{3}+K f_{1} /\left[\mathrm{Cl}^{-}\right]^{2}+K f_{2} /\left[\mathrm{Cl}^{-}\right]+K f_{4}\left[\mathrm{Cl}^{-}\right]}, \\
{\left[\mathrm{CdCl}_{4}{ }^{2-}\right] } & =\frac{K f_{4}\left[\mathrm{Cl}^{-}\right]^{4}\left[\mathrm{Cd}_{T}\right.}{1+K f_{1}\left[\mathrm{Cl}^{-}\right]+K f_{2}\left[\mathrm{Cl}^{-}\right]^{2}+K f_{3}\left[\mathrm{Cl}^{-}\right]^{3}+K f_{4}\left[\mathrm{Cl}^{-}\right]^{4}}
\end{aligned}
$$

These equations indicate that the concentration of $\mathrm{Cl}^{-}$affects the concentration as well as the activity of each Cd-chloro complexe. Therefore, the ionic strength in $\mathrm{CaCl}_{2}$ solutions was calculated using (11):

$$
I=\frac{1}{2} \sum_{i=1}^{n} c_{i} z_{i}^{2}
$$

in which $c$ is the molarity of the ions $i$ and $z_{i}$ is the charge number of the ion $i$. The summation includes all ion concentrations in the solution. Ion activities were calculated using the Davies equation [33]:

$$
\log a_{i}=-0.509 z_{i}^{2}\left(\frac{\sqrt{I}}{1+\sqrt{I}}-0.30 I\right),
$$

where $a$ is the activity of the ion $i$. 
Various forms of the equation were optimized in Microsoft Excel 2010. The distribution diagram of Cdchloro complexes was given as a distribution graph in which the $Y$-axis indicates the percentage of each complex and the $X$-axis represents $\mathrm{pCl}=-\log \left[\mathrm{Cl}^{-}\right]$(Figure 1). If $\left[\mathrm{CaCl}_{2}\right]<0.008 \mathrm{M}, \mathrm{Cd}$ is almost in the form of $\mathrm{Cd}^{2+}$. When the $\mathrm{CaCl}_{2}$ concentration ranges from 0.008 to $0.177 \mathrm{M}$, the major $\mathrm{Cd}$ species is $\mathrm{CdCl}^{+}$and the remaining $\mathrm{Cd}$ is in the form of $\mathrm{Cd}^{2+}$ and $\mathrm{CdCl}_{2}$. The concentrations of both species are similar for $\left[\mathrm{CaCl}_{2}\right]=0.045 \mathrm{M}$.

\section{Results and Discussion}

4.1. Temperature Program. In the absence of a chemical modifier, the GFAAS temperature program was optimized in terms of temperature and time of drying, pyrolysis, and atomization steps. In all tests, the drying step was carried out in two stages, 120 and $250^{\circ} \mathrm{C}$, with the aim of achieving a complete removal of the liquid present in the sample and avoiding any sputtering of sample (Table 1 ). The charring temperature was $300^{\circ} \mathrm{C}[34,35]$ and the furnace temperature on atomization step was $1800^{\circ} \mathrm{C}$ to obtain a maximum-peak absorbance value [34, 36].

4.2. Interference from the Sample Solutions. The peak profiles of $\mathrm{Cd}$ absorption in $\mathrm{CaCl}_{2}$ solutions at various concentrations using the $\mathrm{D}_{2}$-BGC and the HSSR-BGC were shown in Figures 2 and 3, respectively. Decreases of $\mathrm{Cd}$ absorbance were found in the presence of $\mathrm{CaCl}_{2}$ at $0.005,0.01$ and $0.05 \mathrm{M}$ while an increase was observed in the $0.1 \mathrm{M} \mathrm{CaCl}_{2}$ solution despite the use of deuterium lamp and chemical modifier. In contrast, $\mathrm{Cd}$ signal recorded in the $0.001 \mathrm{M} \mathrm{CaCl}_{2}$ solution was similar to $\mathrm{Cd}$ in water. As shown in Figure 2, the $\mathrm{Cd}$ absorbance in $\mathrm{CaCl}_{2}$ solutions was unchanged up to $0.01 \mathrm{M}$ concentration compared with the absorbance from $\mathrm{Cd}$ alone in water. A very small enhancement of $\mathrm{Cd}$ absorbance was found in the presence of 0.05 and $0.1 \mathrm{M} \mathrm{CaCl}_{2}$ from which $\mathrm{Cd}$ concentrations were 1.2 and $1.4 \mu \mathrm{gL}^{-1}$. Even if it was demonstrated that the principal causes for loss of precision could be the variation in the heating characteristics of the furnace, the performance of the technique used for processing the signals is very important [38]. Regarding the peak profiles (Figure 2), the signal processing was so carried out on the basis of peak height (at 24 s; Figure 3) rather than peak area measurements.

Based on the previous consideration, a Cd solution at $0.66 \mu \mathrm{g} \mathrm{L}^{-1}$ in $0.1 \mathrm{M} \mathrm{CaCl}_{2}$ was prepared and 2-, 5-, and 10 -fold serial dilutions were made. Despite the use of the deuterium lamp as a continuum light source for the background correction, the signal processing was impossible (Figure 4; the first solution was not shown). As can be seen in Figure 5, no signal overlapping was obtained using the HSSR-BGC. A first approach of this background correction has been proposed in 1983 by Smith-Hieftje [31] but was rapidly criticized due to its low modulation frequencies (maximum $10 \mathrm{~Hz}$ which were not compatible with the rapid transient signals common to GFAAS experiments. The modulation cycle used in the HSSR-method was 10 times
TABLE 1: Furnace temperature program for Cd determination.

\begin{tabular}{lcccc}
\hline $\begin{array}{l}\text { Furnace } \\
\text { program step }\end{array}$ & $\begin{array}{c}\text { Temperature } \\
\left({ }^{\circ} \mathrm{C}\right)^{\mathrm{a}}\end{array}$ & $\begin{array}{c}\text { Hold time } \\
(\mathrm{s})\end{array}$ & $\begin{array}{c}\text { Ramp rate } \\
\left({ }^{\circ} \mathrm{C} \mathrm{s}^{-1}\right)\end{array}$ & $\begin{array}{c}\text { Argon gas } \\
\text { flow rate } \\
\left(\mathrm{L} \mathrm{min}^{-1}\right)\end{array}$ \\
\hline Drying-1 & $120(150)^{\mathrm{b}}$ & 5 & 24 & 1 \\
Drying-2 & $250(250)^{\mathrm{b}}$ & 5 & 26 & 1 \\
Pyrolysis-1 & $300(500)^{\mathrm{b}}$ & 5 & 10 & 1 \\
Pyrolysis-2 & $300(500)^{\mathrm{b}}$ & $3^{*}$ & 0 & 0 \\
Atomisation & $1800(2200)^{\mathrm{b}}$ & $6^{*}$ & 3400 & 0 (read) \\
Cleaning & $2300(2400)^{\mathrm{b}}$ & 3 & 3400 & 1 \\
\hline
\end{tabular}

${ }^{a}$ Temperature program used in absence of chemical modifier.

${ }^{b}$ Temperature program used in presence of chemical modifier.

*The high-sensitivity mode was applied and the argon flow was stopped.

higher than in the original Smith-Hieftje background correction system). Therefore, the rapid modulation generated by the high frequency $(100 \mathrm{~Hz})$ between currents at low and high levels (from 10 to $100 \mathrm{~mA}$ ) applied to the Cd highintensity boosted discharge hollow-cathode lamp may be of importance in interpolation of transient time-dependent signal fluctuations. On the other hand, whereas $\mathrm{D}_{2}$ corrects for an average background over the full spectral band width, the HSSR-BGC, like the S-H method, corrects at the center of the resonance line. Two distinct signals have been obtained under the analytical conditions, the first being attributed to $\mathrm{Cd}$ (at $24 \mathrm{~s}$ as in Figure 3). It is worth noting that the variation of the $\mathrm{Cd}$ absorbance corresponded well to the dilution factor, reflecting the efficiency of the HSSR-BGC.

4.3. Analytical Figures of Merit. Over the last decade, single extraction of metals in contaminated soils with $0.01 \mathrm{M} \mathrm{CaCl}_{2}$ has become an international method [37, 39, 40]. Calibration curves were so obtained from $\mathrm{Cd}$ stock solution after dilution with $0.01 \mathrm{M} \mathrm{CaCl}_{2}$ solution and the analytical characteristics of the GFAAS were determined in $0.01 \mathrm{M} \mathrm{CaCl}_{2}$ solution. The curve was obtained from 10 calibration plots, ranging from 0.01 to $3.33 \mu \mathrm{g} \mathrm{L}^{-1}$. As shown in Table 2, Cd absorbance correlated well with concentrations. The limits of detection (LOD) and quantification (LOQ), based on three and ten times the standard deviation of the blank values $(n=$ 10) were 10.7 and $35.6 \mathrm{n} \mathrm{L}^{-1}$, respectively. These values were in the same order of magnitude than those obtained using doubly distilled water (LOD $=10.9$ and LOQ = $\left.36.4 \mathrm{n} \mathrm{L}^{-1}\right)$. The characteristic mass $\left(m_{0}\right)$ was defined as the mass of analyte to an integrated absorbance of $0.0044 \mathrm{~s}$ following the relation, $m_{0}=(0.0044 C V) /\left(A_{1}-A_{2}\right)$ in which $C$ is the analyte concentration, $V$ is the introduced volume, and $A_{1}$ and $A_{2}$ are the integrated absorbance of the sample and blank, respectively [41]. The characteristic mass found in $0.01 \mathrm{M} \mathrm{CaCl}_{2}$ solution was $m_{0}=0.34 \mathrm{pg}$. The reproducibility of the analytical method was investigated for the determination of $0.66 \mu \mathrm{g} \mathrm{L}^{-1} \mathrm{Cd}$ in $0.01 \mathrm{M} \mathrm{CaCl}_{2}$ solution (Figure 6). The relative standard deviation (RSD) was $4.8 \%$ $(n=10)$.

It is well known that the high temperature applied for the Cd pyrolysis decreases the lifetime of graphite tubes as 


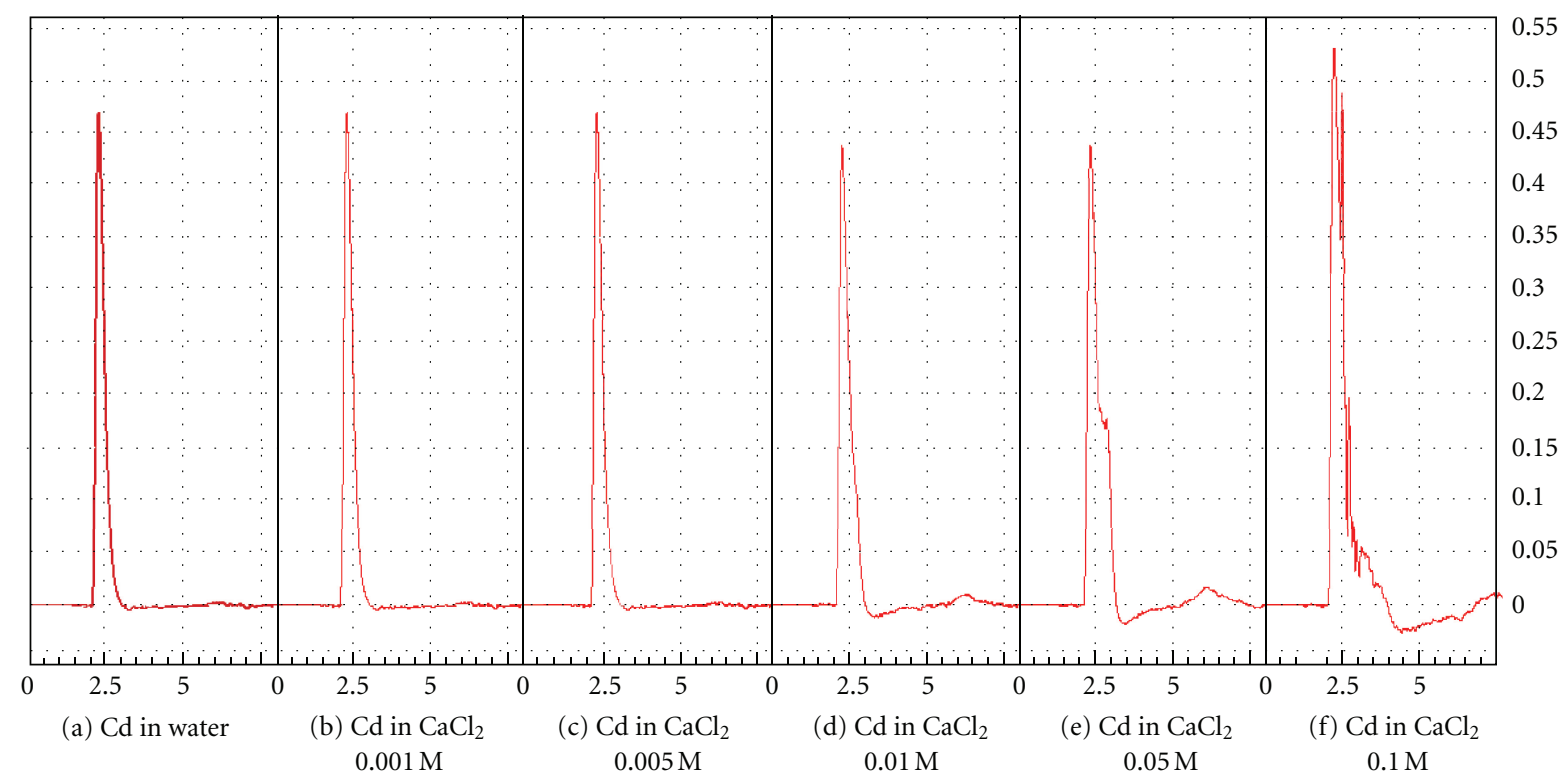

Figure 2: Absorption-time profiles of $\mathrm{Cd}$ at $1 \mu \mathrm{g} \mathrm{L}-1$ resulting from atomization of $\mathrm{CaCl}_{2}$ solution at various concentrations using the $\mathrm{D}_{2}$ BGC.

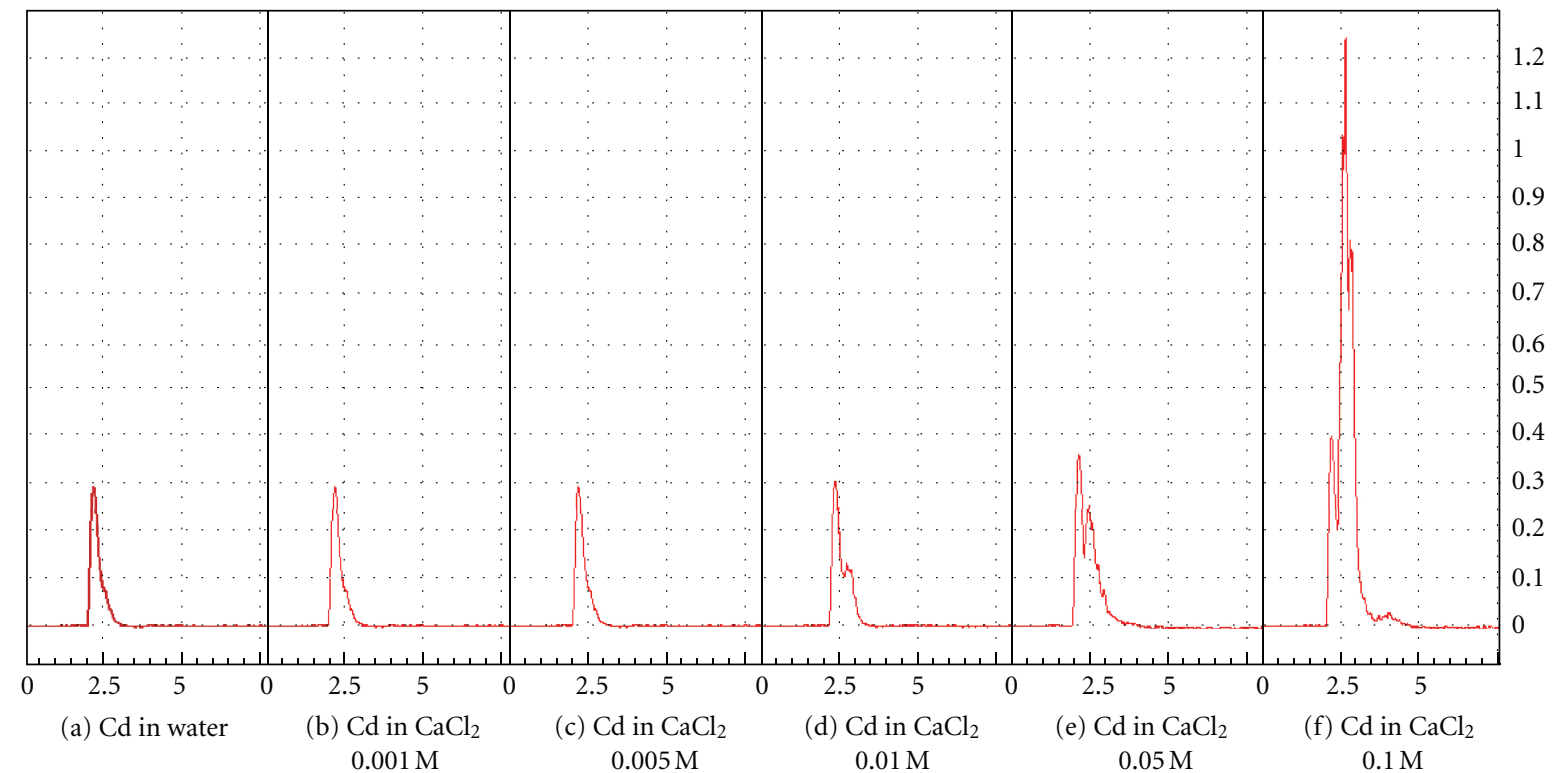

Figure 3: Absorption-time profiles of $\mathrm{Cd}$ at $1 \mu \mathrm{g} \mathrm{L}{ }^{-1}$ resulting from atomization of $\mathrm{CaCl}_{2}$ solution at various concentrations using the HSSR-BGC.

well as the corrosive action of some modifiers [42]. The lifetime of the graphite tube using the chemical modifier and the high temperature conditions was around 650 firings. Without any chemical modifiers, the lifetime of the graphite tube was up to 1600 firings. If the HSSR method appears as an efficient method to avoid interferences in the $\mathrm{Cd}$ determination using GFAAS without any chemical modifier in the experimental conditions, this method also improves the life time of graphite tubes.
4.4. Quality Control of Analytical Data. Calcium chloride at $0.01 \mathrm{M}$ is widely used to evaluate the environmental availability of $\mathrm{Cd}$ in contaminated soils $[21,39,43-45]$ and to monitor the changes in $\mathrm{CaCl}_{2}$-extractable $\mathrm{Cd}$ generated by a soil remediation technique [46-48]. It is so very important to obtain a good determination of $\mathrm{CaCl}_{2}$-extractable $\mathrm{Cd}$ concentrations in contaminated soils.

The quality of the combined single extraction and analytical technique was evaluated using certified and standard 


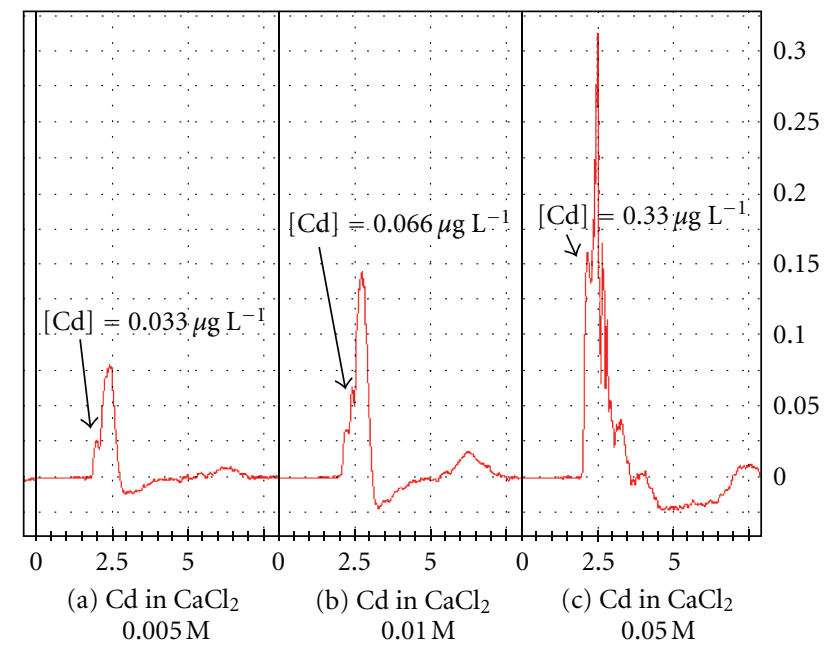

FIgURE 4: Absorbance of $\mathrm{Cd}$ in $\mathrm{CaCl}_{2}$ solution after successive dilutions using the $\mathrm{D}_{2}$ - $\mathrm{BGC}$.
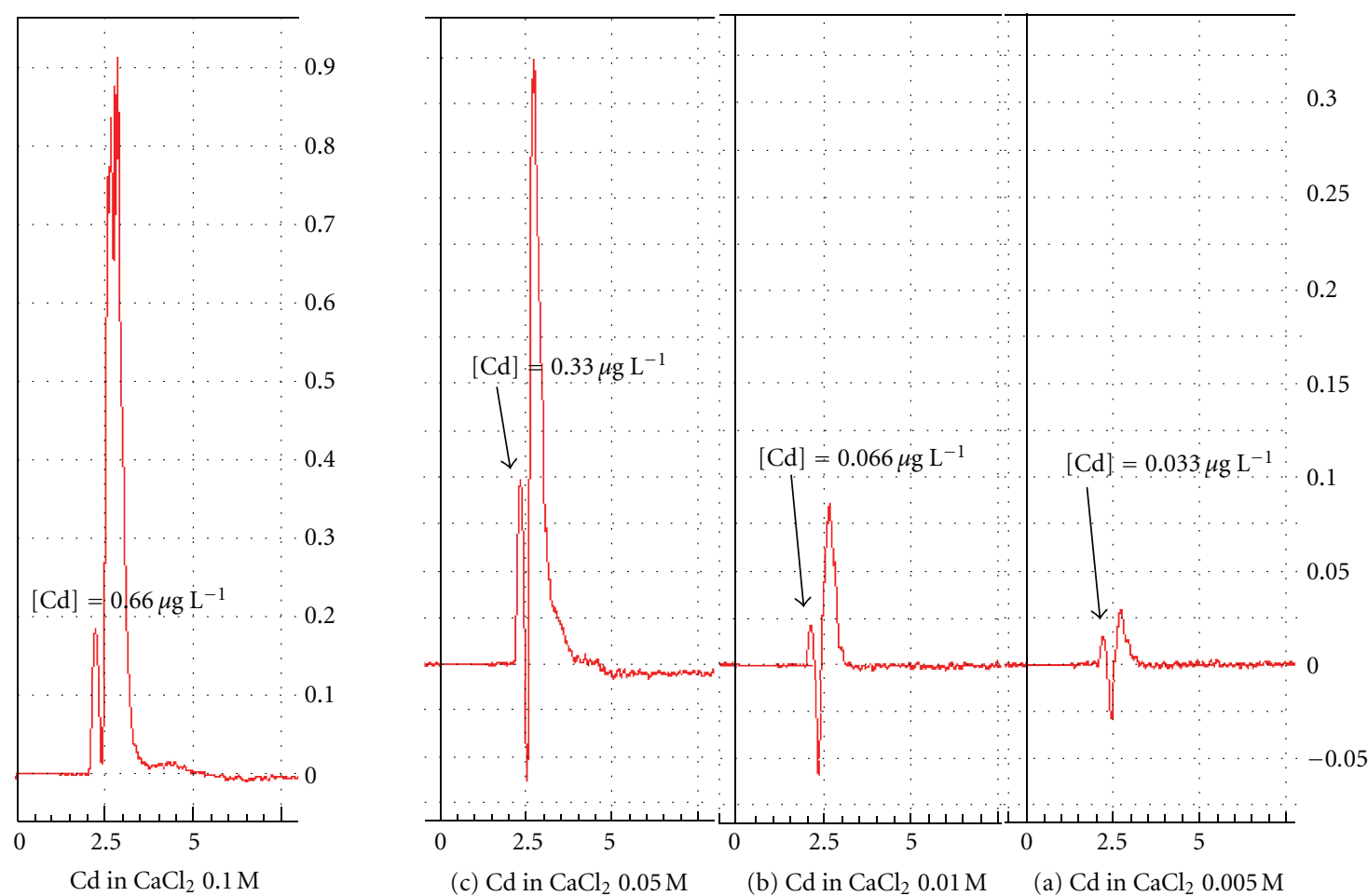

(c) $\mathrm{Cd}$ in $\mathrm{CaCl}_{2} 0.05 \mathrm{M}$

(b) $\mathrm{Cd}$ in $\mathrm{CaCl}_{2} 0.01 \mathrm{M}$

(a) $\mathrm{Cd}$ in $\mathrm{CaCl}_{2} 0.005 \mathrm{M}$

FIGURE 5: Absorbance of $\mathrm{Cd}$ in $\mathrm{CaCl}_{2}$ solution after successive dilutions using the HSSR-BGC.

reference materials (BCR-483, BCR-701, BCR-141R, and NIST 2710a). No significant difference between the mean extractable $\mathrm{Cd}$ measured in reference materials and the certified, or indicative Cd values was found (Table 3). The ratio $\mathrm{As} / \mathrm{Cd}$ and $\mathrm{Fe} / \mathrm{Cd}$ ranged from 0.11 to 1.83 and 1.76 to 3.77, respectively. Therefore, the presence of As and Fe in $\mathrm{CaCl}_{2}$ extracting solution cannot lead to a substantial modification in the Cd concentrations $[29,30]$. The lowest $\mathrm{Cd}$ concentrations measured in the $\mathrm{CaCl}_{2}$ extracting solution were provided by the BCR-141R material. Very high standard deviation (SD) value was obtained using the deuterium lamp and chemical modifier. This value explains the low precision defined as the relative standard deviation ( $\mathrm{RSD}=40.7 \%$ ) and the fact that the two mean Cd values obtained using the two analytical methods were not significantly different. Regarding the results for the BCR-141R material, an underestimation of the mean extractable Cd concentration using the deuterium lamp combined to the chemical modifier was suspected. As a consequence, to prevent the increase of the ratio $\mathrm{Cl} / \mathrm{Cd}$ when the $\mathrm{Cd}$ concentration is too high to 


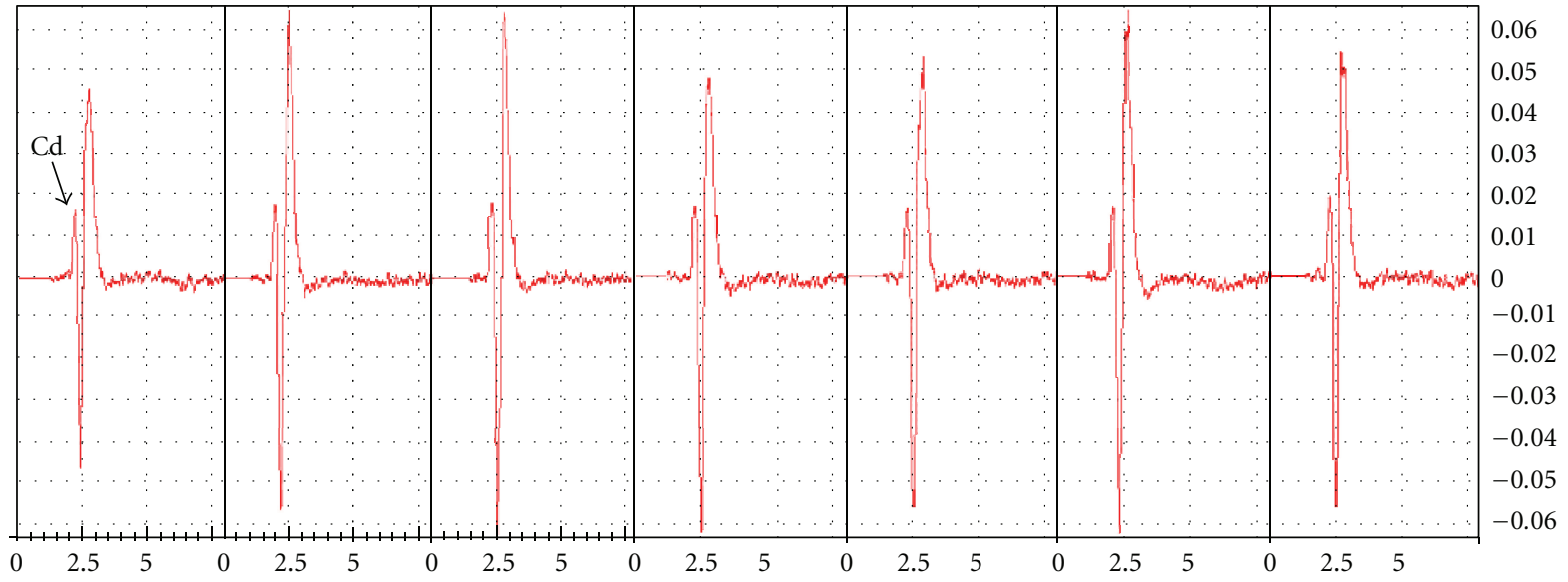

FIgure 6: Reproducibility of the Cd signal (at $0.66 \mu \mathrm{g} \mathrm{L}^{-1}$ ) in $0.01 \mathrm{M} \mathrm{CaCl}_{2}$ solution using the HSSR-BGC.

be determined by GFAAS, dilutions were carried out with doubly distilled water in the following experiments instead of the $0.01 \mathrm{M} \mathrm{CaCl}_{2}$ solution.

4.5. Calcium-Chloride-Extractable Cd in Contaminated Soils. For each contaminated soil, the $0.01 \mathrm{M} \mathrm{CaCl}_{2}$-extractable concentration of $\mathrm{Cd}$ was determined by means of GFAAS combined with three modes: HSSR-BGC without any modifier, $\mathrm{D}_{2}$-BGC with palladium as chemical modifier [24], and $\mathrm{D}_{2}$-BGC without any modifier. With the last mode, $\mathrm{Cd}$ concentrations were much higher than those measured using the two other modes. The ANCOVA (Bonferroni, Fischer and Tuckey post-hoc tests) statistical analyses showed significant differences between the two first datasets and the third. These differences can be explain by the presence of As and Fe in the extracting solution rather than $\mathrm{CaCl}_{2}$. The absorption lines of As at $228.812 \mathrm{~nm}$ and $\mathrm{Fe}$ at 228.763 and 228.725 may cause highly structured spectral interferences that the deuterium lamp is not be able to correct $[26,27]$. For contaminated soil samples (CS1 to CS9), statistical tests showed no significant differences between the average $\mathrm{Cd}$ concentrations measured using the HSSR-BGC method and the $\mathrm{D}_{2}$-BGC method combined with the chemical modifier. This result attests that the HSSR-BGC mode is an efficient background compensation technique to minimize the spectral interferences caused by concomitant species during the Cd measurements in GFAAS. Because all samples were diluted with doubly distilled water (from $1: 4$ to $1: 100$ ), the concentration of $\mathrm{CaCl}_{2}$ ranged from 0.0025 to $0.0001 \mathrm{M}(2.3<\mathrm{pCl}<4)$. Therefore, more than $73 \%$ of $\mathrm{Cd}$ in $\mathrm{CaCl}_{2}$ solution was found as $\mathrm{Cd}^{2+}$ (Figure 1) and no decrease of the Cd absorbance was recorded using the $\mathrm{D}_{2}$ method. The real problem was the determination of $\mathrm{Cd}$ in extracts from soil samples CS10 to CS22 for which statistical differences were found between the two modes. The $0.01 \mathrm{M} \mathrm{CaCl}_{2}$-extractable concentrations of $\mathrm{Cd}$ were the lowest and the $\mathrm{Cd}$ concentration measured using the deuterium lamp combined with the chemical modifier were systematically below those measured using the HSSR method (Table 3 ). Taking into account the ratio solid : liquid $(1: 10)$, these concentrations were obtained after low dilution with doubly distilled water (1:1.25 for CS10, CS11, and CS12) and without any dilution for the other (CS13-CS22). Thus, the concentration of $\mathrm{CaCl}_{2}$ ranged from 0.01 to $0.008 \mathrm{M}$. With regards to Figure 1 , the speciation of $\mathrm{Cd}$ in the $\mathrm{CaCl}_{2}$ extracting solution is in the form of $\mathrm{Cd}^{2+}(43-50 \%)$ and in the form of $\mathrm{CdCl}^{+}(50-52 \%$, resp.). The presence of this $\mathrm{Cd}$-chloro complexe in the graphite tube probably caused chloride interferences during the atomization step. These interferences could explain the decrease of the absorbance of the Cd signal as observed in Figure 2 using the deuterium lamp combined with the chemical modifier whereas no loss of $\mathrm{Cd}$ absorbance was observed in the experimental conditions. This subject is of major concern in the determination of a $\mathrm{Cd}$ in plants grown on soils with high sodium chloride concentration and in the determination of Cd speciation using the DGT (diffusion gradients thin films) technique. Indeed, in each case, the formation of Cd-chloro complex was demonstrated and the determination of $\mathrm{Cd}$ using GFAAS can be a real problem $[7,9]$.

\section{Conclusions}

The measurements of $\mathrm{Cd}$ in $\mathrm{CaCl}_{2}$ solutions at various concentrations were performed using GFAAS with two background correction systems. The first was based on the wellknown deuterium background correction and the second involved the use of a single Cd hollow-cathode lamp pulsed with currents ranging from 10 to $100 \mathrm{~mA}$ with a frequency of $100 \mathrm{~Hz}$. Depending on the $\mathrm{CaCl}_{2}$ concentrations, decrease and increase of the $\mathrm{Cd}$ absorbance signal occurred with the conventional background corrector. In contrast, the HSSRBGC appeared to be a more versatile technique for the compensation of interferences caused by the presence of $\mathrm{CaCl}_{2}$ over the course of the determination of $\mathrm{Cd}$. The high frequency applied to pass from low to high current intensities generated more than one peak profile, the first being attributed to the $\mathrm{Cd}$ absorbance signal. Very low detection limit and characteristic mass values of the analyte in $0.01 \mathrm{M} \mathrm{CaCl}_{2}$ solution were found using the HSSR-BGC, 
TABLE 2: Equation of calibration range, limits of detection (LOD) and quantification (LOQ), and characteristic mass $\left(m_{0}\right)$ for peak absorption.

\begin{tabular}{|c|c|c|c|c|}
\hline $\begin{array}{l}\text { Calibration range } \\
\left(\mu \mathrm{g} \mathrm{L}^{-1}\right)\end{array}$ & Equation of calibration curves & $\begin{array}{c}\text { LOD } \\
\left(\mathrm{ng} \mathrm{L}^{-1}\right)\end{array}$ & $\begin{array}{c}\text { LOQ } \\
\left(\mathrm{ng} \mathrm{L}^{-1}\right) \\
\end{array}$ & $\begin{array}{l}m_{0} \\
(\mathrm{pg})\end{array}$ \\
\hline $0.01-2$ & $\begin{array}{l}\text { Abs }=0.2579[\mathrm{Cd}]+0.0039 \\
R^{2}=0.9998\end{array}$ & 10.7 & 35.6 & 0.34 \\
\hline $0.01-3.33$ & $\begin{array}{l}\text { Abs }=-2.8 \cdot 10^{-2}[\mathrm{Cd}]^{2}+0.3125[\mathrm{Cd}]+0.0123 \\
R^{2}=0.9993\end{array}$ & 10.7 & 35.6 & 0.31 \\
\hline
\end{tabular}

Abs means integrated absorbance and $[\mathrm{Cd}]$ is in $\mu \mathrm{g} \mathrm{L}^{-1}$. Units for slopes are in $\mathrm{L} \mu \mathrm{g}^{-1}$.

TABLE 3: Extractable Cd in $0.01 \mathrm{M} \mathrm{CaCl}_{2}$ soil extracts (mean \pm standard deviation $\left.(\mathrm{SD}) ; n=6\right)$.

\begin{tabular}{|c|c|c|c|c|c|}
\hline Samples & $\begin{array}{l}\text { Fe in this work } \\
\quad\left(\mathrm{mg} \mathrm{kg}^{-1}\right)\end{array}$ & $\begin{array}{l}\text { As in this work } \\
\quad\left(\mu \mathrm{gg}^{-1}\right)\end{array}$ & $\begin{array}{c}\mathrm{Cd} \\
\mathrm{HSSR}^{\mathrm{B}} \mathrm{BGC}^{\mathrm{a}} \\
\left(\mu \mathrm{g} \mathrm{kg}{ }^{-1}\right)\end{array}$ & $\begin{array}{c}\mathrm{Cd} \\
\mathrm{D}_{2}-\mathrm{BGC} \\
\left(\mu \mathrm{g} \mathrm{kg}^{-1}\right)\end{array}$ & $\begin{array}{c}\mathrm{Cd} \\
\mathrm{D}_{2}-\mathrm{BGC}^{\mathrm{a}} \\
\left(\mu \mathrm{g} \mathrm{kg}^{-1}\right)\end{array}$ \\
\hline BCR-483 & $0.98 \pm 0.15$ & $883 \pm 30$ & $482 \pm 19^{b, c}$ & $473 \pm 19$ & ND \\
\hline BCR-701 & $0.62 \pm 0.07$ & $65 \pm 5$ & $352 \pm 6$ & $349 \pm 15$ & ND \\
\hline BCR-141R & $0.55 \pm 0.03$ & $18 \pm 1$ & $146 \pm 5$ & $113 \pm 46$ & ND \\
\hline NIST $2710 \mathrm{a}$ & $14.10 \pm 0.67$ & $455 \pm 46$ & $3979 \pm 58$ & $4015 \pm 60$ & ND \\
\hline CS1 & $1.42 \pm 0.16$ & $1336 \pm 157$ & $2220 \pm 9$ & $2217 \pm 6$ & $2332 \pm 10$ \\
\hline CS2 & $0.12 \pm 0.03$ & $1467 \pm 158$ & $444 \pm 9$ & $443 \pm 9$ & $556 \pm 18$ \\
\hline CS3 & $2.91 \pm 1.75$ & $83 \pm 9$ & $145 \pm 4$ & $132 \pm 10$ & $447 \pm 19$ \\
\hline $\mathrm{CS} 4$ & $0.39 \pm 0.04$ & $1582 \pm 57$ & $139 \pm 6$ & $138 \pm 9$ & $147 \pm 6$ \\
\hline CS5 & $3.90 \pm 0.38$ & $192 \pm 7$ & $125 \pm 9$ & $120 \pm 19$ & $342 \pm 10$ \\
\hline CS6 & $3.94 \pm 0.96$ & $334 \pm 35$ & $114 \pm 9$ & $122 \pm 9$ & $287 \pm 32$ \\
\hline CS7 & $3.03 \pm 0.26$ & $77 \pm 10$ & $85 \pm 10$ & $73 \pm 6$ & $184 \pm 10$ \\
\hline CS8 & $0.39 \pm 0.13$ & $1515 \pm 170$ & $64 \pm 6$ & $66 \pm 6$ & $120 \pm 19$ \\
\hline CS9 & $4.27 \pm 1.29$ & $335 \pm 24$ & $54 \pm 3$ & $55 \pm 3$ & $161 \pm 6$ \\
\hline CS10 & $0.16 \pm 0.03$ & $1630 \pm 89$ & $39 \pm 10$ & $25 \pm 12$ & $289 \pm 9$ \\
\hline CS11 & $3.40 \pm 0.80$ & $64 \pm 3$ & $38 \pm 3$ & $20 \pm 3$ & $94 \pm 9$ \\
\hline CS12 & $5.30 \pm 1.05$ & $168 \pm 7$ & $32 \pm 1$ & $24 \pm 5$ & $67 \pm 6$ \\
\hline CS13 & $2.25 \pm 0.33$ & $111 \pm 3$ & $26.3 \pm 0.7$ & $20.2 \pm 3.5$ & ND \\
\hline CS14 & $3.56 \pm 0.18$ & $208 \pm 5$ & $23.6 \pm 0.3$ & $17.9 \pm 3.1$ & ND \\
\hline CS15 & $1.44 \pm 0.26$ & $151 \pm 7$ & $18.3 \pm 0.5$ & $13.2 \pm 3.3$ & $\mathrm{ND}$ \\
\hline CS16 & $1.92 \pm 0.12$ & $186 \pm 6$ & $16.7 \pm 0.7$ & $11.1 \pm 2.9$ & ND \\
\hline CS17 & $0.22 \pm 0.08$ & $81 \pm 6$ & $14.0 \pm 0.7$ & $9.3 \pm 2.9$ & ND \\
\hline CS18 & $0.53 \pm 0.15$ & $78 \pm 4$ & $13.3 \pm 0.4$ & $8.9 \pm 1.8$ & ND \\
\hline CS19 & $2.16 \pm 0.30$ & $62 \pm 3$ & $10.2 \pm 0.2$ & $6.3 \pm 0.2$ & ND \\
\hline CS20 & $0.81 \pm 0.21$ & $35 \pm 3$ & $7.4 \pm 0.5$ & No value & $\mathrm{ND}$ \\
\hline CS21 & $0.24 \pm 0.08$ & $12 \pm 1$ & $5.7 \pm 0.3$ & No value & $\mathrm{ND}$ \\
\hline CS22 & $0.12 \pm 0.04$ & $15 \pm 1$ & $3.3 \pm 0.2$ & No value & ND \\
\hline
\end{tabular}

${ }^{a}$ In absence of chemical modifier.

${ }^{\mathrm{b}}$ Indicative value: $[\mathrm{Cd}]=450 \pm 50 \mu \mathrm{g} \mathrm{kg}^{-1}$.

'From Pueyo et al. (2004), [Cd] $=480 \pm 10 \mu \mathrm{g} \mathrm{kg}^{-1}$ (ICP-MS) [37].

ND: not determined. 
$10.9 \mu \mathrm{g} \mathrm{L}^{-1}$ and $0.34 \mathrm{pg}$, respectively. With regards to the results, dilution of solutions with water is recommended to avoid the increase of the ratio $\mathrm{Cl} / \mathrm{Cd}$ when the $\mathrm{Cd}$ concentration is too high to be determined by GFAAS. The HSSR-BGC and the $\mathrm{D}_{2}$-BGC (combined with a chemical modifier) can be used to prevent the As and $\mathrm{Fe}$ interferences. In contrast, for a very low-factor dilution, large decreases of the $\mathrm{Cd}$ absorbance signal were observed using the $\mathrm{D}_{2}$ - $\mathrm{BGC}$ due to the presence of $\mathrm{CdCl}^{+}$species. In this case, the HSSRmethod is highly recommended.

\section{Appendix}

\section{Standard}

NF ISO 11464. Soil Quality: Pretreatment of samples for physicochemical analyses. AFNOR, 1994, 9 p.

NF ISO 11465. Soil Quality: Determination of dry matter and water content on a mass basis: gravimetric method. AFNOR, 1994, 4 p.

\section{References}

[1] W. Lund, "Speciation analysis-why and how?" Fresenius' Journal of Analytical Chemistry, vol. 337, no. 5, pp. 557-564, 1990.

[2] M. Erten-Unal, B. G. Wixson, N. Gale, and J. L. Pitt, "Evaluation of toxicity, bioavailability and speciation of lead, zinc and cadmium in mine/mill wastewaters," Chemical Speciation and Bioavailability, vol. 10, no. 2, pp. 37-46, 1998.

[3] S. Sauvé, W. A. Norvell, M. McBride, and W. Hendershot, "Speciation and complexation of cadmium in extracted soil solutions," Environmental Science and Technology, vol. 34, no. 2, pp. 291-296, 2000.

[4] S. Sauvé, S. Manna, M. C. Turmel, A. G. Roy, and F. Courchesne, "Solid-solution partitioning of $\mathrm{Cd}, \mathrm{Cu}, \mathrm{Ni}, \mathrm{Pb}$, and $\mathrm{Zn}$ in the organic horizons of a forest soil," Environmental Science and Technology, vol. 37, no. 22, pp. 5191-5196, 2003.

[5] U. J. López-Chuken, S. D. Young, and J. L. Guzmán-Mar, "Evaluating a "biotic ligand model" applied to chlorideenhanced Cd uptake by Brassica juncea from nutrient solution at constant $\mathrm{Cd}^{2+}$ activity," Environmental Technology, vol. 31, no. 3, pp. 307-318, 2010.

[6] C. F. Calhôa, M. S. Monteiro, A. M. V. M. Soares, and R. M. Mann, "The influence of metal speciation on the bioavailability and sub-cellular distribution of cadmium to the terrestrial isopod, Porcellio dilatatus," Chemosphere, vol. 83, no. 4, pp. 531-537, 2011.

[7] K. Weggler-Beaton, M. J. McLaughlin, and R. D. Graham, "Salinity increases cadmium uptake by wheat and Swiss chard from soil amended with biosolids," Australian Journal of Soil Research, vol. 38, no. 1, pp. 37-45, 2000.

[8] K. Weggler, M. J. McLaughlin, and R. D. Graham, "Effect of chloride in soil solution on the plant availability of biosolidborne cadmium," Journal of Environmental Quality, vol. 33, no. 2, pp. 496-504, 2004.

[9] E. R. Unsworth, H. Zhang, and W. Davison, "Use of diffusive gradients in thin films to measure cadmium speciation in solutions with synthetic and natural ligands: comparison with model predictions," Environmental Science and Technology, vol. 39, no. 2, pp. 624-630, 2005.
[10] E. Smolders, "Effect of $\mathrm{Cl}$ on Cd uptake by Swiss chard in nutrient solutions," Plant and Soil, vol. 179, no. 1, pp. 57-64, 1996.

[11] M. J. McLaughlin, B. A. Zarcinas, D. P. Stevens, and N. Cook, "Soil testing for heavy metals," Communications in Soil Science and Plant Analysis, vol. 31, no. 11-14, pp. 1661-1700, 2000.

[12] E. Smolders, "Cadmium availability in soils and identification of high risk soils, environmental cadmium in the food chain: sources, pathways and risks," in Proceedings of the International Workshop on Software and Compilers for Embedded Systems (SCOPES '09), Brussels, Belgium, 2000.

[13] L. Recatalá, J. Sánchez, C. Arbelo, and D. Sacristán, “Testing the validity of a $\mathrm{Cd}$ soil quality standard in representative Mediterranean agricultural soils under an accumulator crop," Science of the Total Environment, vol. 409, no. 1, pp. 9-18, 2010.

[14] F. Madrid, R. Reinoso, M. C. Florido et al., "Estimating the extractability of potentially toxic metals in urban soils: a comparison of several extracting solutions," Environmental Pollution, vol. 147, no. 3, pp. 713-722, 2007.

[15] A. Polettini, R. Pomi, and E. Rolle, "The effect of operating variables on chelant-assisted remediation of contaminated dredged sediment," Chemosphere, vol. 66, no. 5, pp. 866-877, 2007.

[16] C. R. M. Rao, A. Sahuquillo, and J. F. Lopez Sanchez, "A review of the different methods applied in environmental geochemistry for single and sequential extraction of trace elements in soils and related materials," Water, Air, and Soil Pollution, vol. 189, no. 1-4, pp. 291-333, 2008.

[17] A. Hass and P. Fine, "Sequential selective extraction procedures for the study of heavy metals in soils, sediments, and waste materialsa critical review," Critical Reviews in Environmental Science and Technology, vol. 40, no. 5, pp. 365399, 2010.

[18] B. F. F. Pereira, D. E. Rozane, S. R. Araújo et al., "Cadmium availability and accumulation by lettuce and rice," Revista Brasileira de Ciencia do Solo, vol. 35, no. 2, pp. 645-654, 2011.

[19] V. J. G. Houba, T. M. Lexmond, I. Novozamsky, and J. J. Van Der Lee, "State of the art and future developments in soil analysis for bioavailability assessment," Science of the Total Environment, vol. 178, pp. 21-28, 1996.

[20] P. Andrewes, R. M. Town, M. J. Hedley, and P. Loganathan, "Measurement of plant-available cadmium in New Zealand soils," Australian Journal of Soil Research, vol. 34, no. 3, pp. 441-452, 1996.

[21] I. Novozamsky, M. Th. Lexmond, and V. J. G. Houba, "A single extraction procedure of soil for evaluation of uptake of some heavy metals by plants," International Journal of Environmental Analytical Chemistry, vol. 51, pp. 47-58, 1993.

[22] T. Sterckeman, J. Perriguey, M. Caël, C. Schwartz, and J. L. Morel, "Applying a mechanistic model to cadmium uptake by Zea mays and Thlaspi caerulescens: consequences for the assessment of the soil quantity and capacity factors," Plant and Soil, vol. 262, no. 1-2, pp. 289-302, 2004.

[23] X. Yin, G. Schlemmer, and B. Welz, "Cadmium determination in biological materials using graphite furnace atomic absorption spectrometry with palladium nitrate-ammonium nitrate modifier," Analytical Chemistry, vol. 59, no. 10, pp. 1462-1466, 1987.

[24] J. Creed, T. Martin, L. Lobring, and J. O’Dell, “Minimizing chloride interferences produced by combination acid digestion using palladium and hydrogen as a matrix modifier in graphite furnace atomic absorption spectrometry," Environmental Science and Technology, vol. 26, no. 1, pp. 102-106, 1992. 
[25] K. Matsusaki, "Mechanism and removal of halide interferences in the determination of metals by atomic absorption spectrometry with electrothermal atomization," Analytica Chimica Acta, vol. 141, pp. 233-240, 1982.

[26] J. C. Feo, M. A. Castro, J. M. Lumbreras, B. De Celis, and A. J. Aller, "Nickel as a chemical modifier for sensitivity enhancement and fast atomization processes in electrothermal atomic absorption spectrometric determination of cadmium in biological and environmental samples," Analytical Sciences, vol. 19, no. 12, pp. 1631-1636, 2003.

[27] J. Y. Cabon, "Determination of $\mathrm{Cd}$ and $\mathrm{Pb}$ in seawater by graphite furnace atomic absorption spectrometry with the use of hydrofluoric acid as a chemical modifier," Spectrochimica Acta B, vol. 57, no. 3, pp. 513-524, 2002.

[28] M. Savio, S. Cerutti, L. D. Martinez, P. Smichowski, and R. A. Gil, "Study of matrix effects and spectral interferences in the determination of lead in sediments, sludges and soils by SR-ETAAS using slurry sampling," Talanta, vol. 82, no. 2, pp. 523-527, 2010.

[29] U. Oppermann, J. Schram, and D. Felkel, "Improved background compensation in atomic absorption spectrometry using the high speed self reversal method," Spectrochimica Acta $B$, vol. 58, no. 8, pp. 1567-1572, 2003.

[30] C. Waterlot and F. Douay, "The problem of arsenic interference in the analysis of Cd to evaluate its extractability in soils contaminated by arsenic," Talanta, vol. 80, no. 2, pp. 716-722, 2009.

[31] S. B. Smith and G. M. Hieftje, "A new background-correction method for atomic absorption spectrometry," Applied Spectroscopy, vol. 37, no. 5, pp. 419-424, 1983.

[32] M. B. McBride, Environmental Chemistry of Soils, Oxford University Press, New York, NY, USA, 1994.

[33] C. W. Davies, Ion Association, Butterworths, London, UK, 1962.

[34] T. Stafilov, D. Zendelovska, G. Pavlovska, and K. Čundeva, "Determination of trace elements in dolomite and gypsum by atomic absorption spectrometry: overcoming the matrix interference by flotation separation," Spectrochimica Acta B, vol. 57, no. 5, pp. 907-917, 2002.

[35] C. S. Nomura, P. R. M. Correia, P. V. Oliveira, and E. Oliveira, "W $+\mathrm{Rh}$ as permanent chemical modifier in simultaneous atomic absorption spectrometry: interference studies on As, $\mathrm{Cd}, \mathrm{Pb}$ and Se determination," Journal of the Brazilian Chemical Society, vol. 15, no. 1, pp. 75-82, 2004.

[36] A. Zacharia, S. Gucer, B. Izgi, A. Chebotarev, and H. Karaaslan, "Direct atomic absorption spectrometry determination of tin, lead, cadmium and zinc in high-purity graphite with flame furnace atomizer," Talanta, vol. 72, no. 2, pp. 825-830, 2007.

[37] M. Pueyo, J. F. López-Sánchez, and G. Rauret, "Assessment of $\mathrm{CaCl}_{2}, \mathrm{NaNO}_{3}$ and $\mathrm{NH}_{4} \mathrm{NO}_{3}$ extraction procedures for the study of $\mathrm{Cd}, \mathrm{Cu}, \mathrm{Pb}$ and $\mathrm{Zn}$ extractability in contaminated soils," Analytica Chimica Acta, vol. 504, no. 2, pp. 217-226, 2004.

[38] U. Kale and E. Voigtman, "Signal processing of transient atomic absorption signals," Spectrochimica Acta B, vol. 50, no. 12, pp. 1531-1541, 1995.

[39] M. G. Whitten and G. S. P. Ritchie, "Calcium chloride extractable cadmium as an estimate of cadmium uptake by subterranean clover," Australian Journal of Soil Research, vol. 29, pp. 215-221, 1991.

[40] A. M. Wightwick, G. Croatto, G. Allinson, and N. W. Menzies, "Use of reference soils in determinations of $0.01 \mathrm{~m}$ calcium chloride available metals," Communications in Soil Science and Plant Analysis, vol. 41, no. 21, pp. 2602-2612, 2010.
[41] T. A. M. Ure, L. R. P. Butler, B. V. L. 'vov, I. Rubeska, and R. Sturgeon, "Terms related to electrothermal atomisation," Pure and Applied Chemistry, vol. 64, pp. 253-259, 1992.

[42] D. L. Tsalev, V. I. Slaveykova, L. Lampugnani, A. D’Ulivo, and R. Georgieva, "Permanent modification in electrothermal atomic absorption spectrometry-advances, anticipations and reality," Spectrochimica Acta B, vol. 55, no. 5, pp. 473-490, 2000.

[43] M. K. Zhang, Z. Y. Liu, and H. Wang, "Use of single extraction methods to predict bioavailability of heavy metals in polluted soils to rice," Communications in Soil Science and Plant Analysis, vol. 41, no. 7, pp. 820-831, 2010.

[44] A. Kabata-Pendias, "Soil-plant transfer of trace elements-an environmental issue," Geoderma, vol. 122, no. 2-4, pp. 143149, 2004.

[45] A. Pérez-de-Mora, E. Madejón, P. Burgos, and F. Cabrera, "Trace element availability and plant growth in a mine-spill contaminated soil under assisted natural remediation I. Soils," Science of the Total Environment, vol. 363, no. 1-3, pp. 28-37, 2006.

[46] A. Pérez-de-Mora, E. Madejón, P. Burgos, and F. Cabrera, "Trace element availability and plant growth in a minespill-contaminated soil under assisted natural remediation. II. Plants," Science of the Total Environment, vol. 363, no. 1-3, pp. 38-45, 2006.

[47] C. Waterlot, C. Pruvot, H. Ciesielski, and F. Douay, "Effects of a phosphorus amendment and the $\mathrm{pH}$ of water used for watering on the mobility and phytoavailability of $\mathrm{Cd}, \mathrm{Pb}$ and $\mathrm{Zn}$ in highly contaminated kitchen garden soils," Ecological Engineering, vol. 37, no. 7, pp. 1081-1093, 2011.

[48] B. Pourrut, A. Lopareva-Pohu, C. Pruvot et al., "Assessment of fly ash-aided phytostabilisation of highly contaminated soils after an 8-year field trial-Part 2: influence on plants," Science of the Total Environment, vol. 409, no. 3, pp. 4504-4510, 2011. 


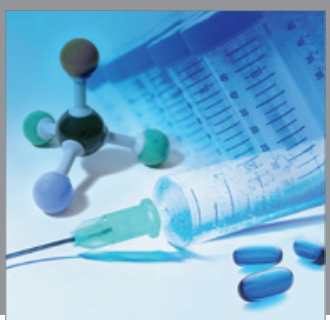

International Journal of

Medicinal Chemistry

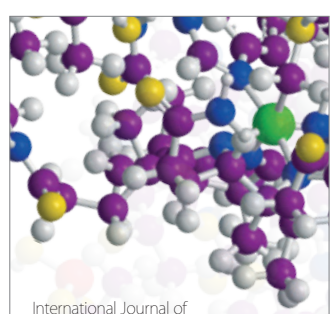

Carbohydrate Chemistry

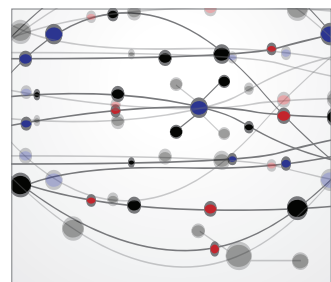

The Scientific World Journal
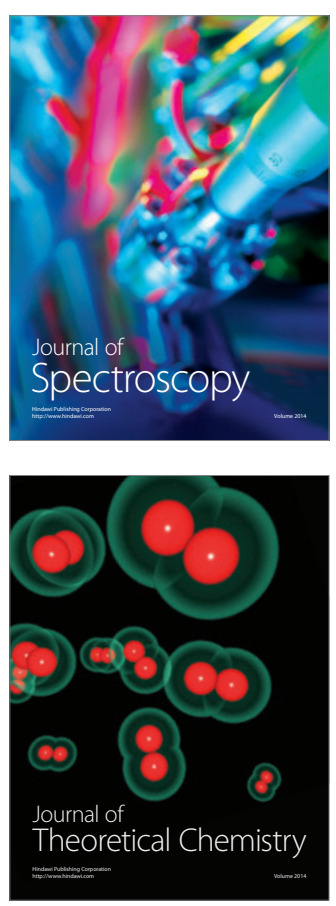
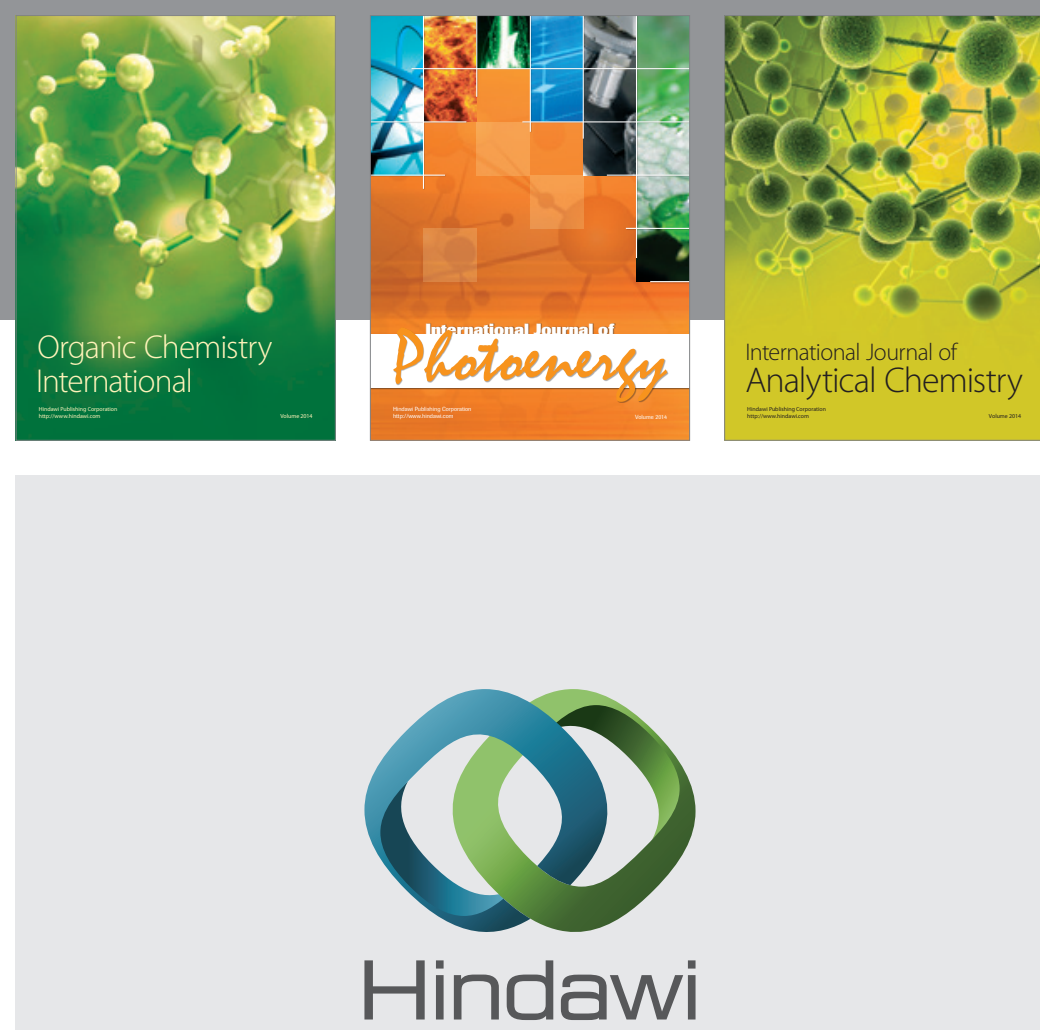

Submit your manuscripts at

http://www.hindawi.com
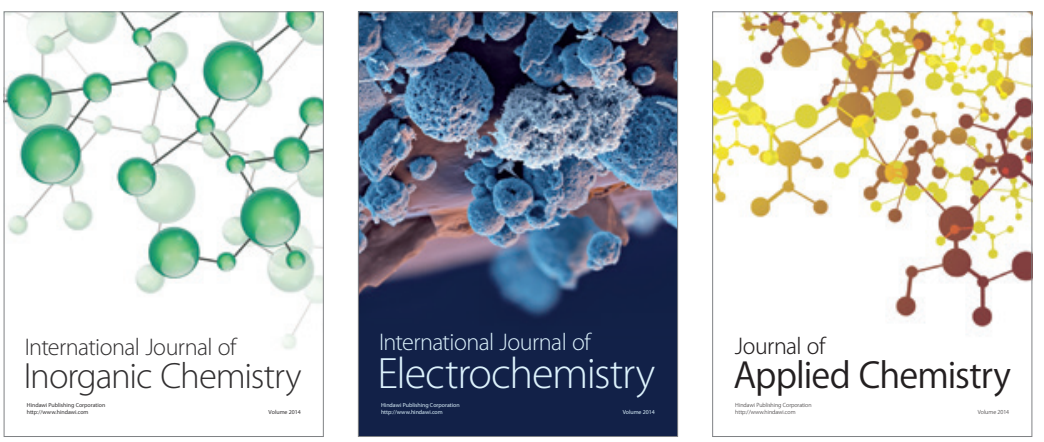

Journal of

Applied Chemistry
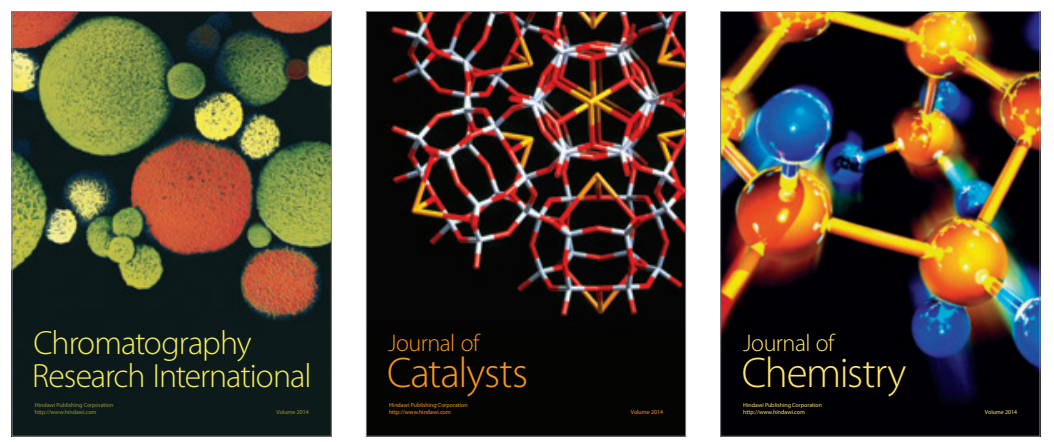
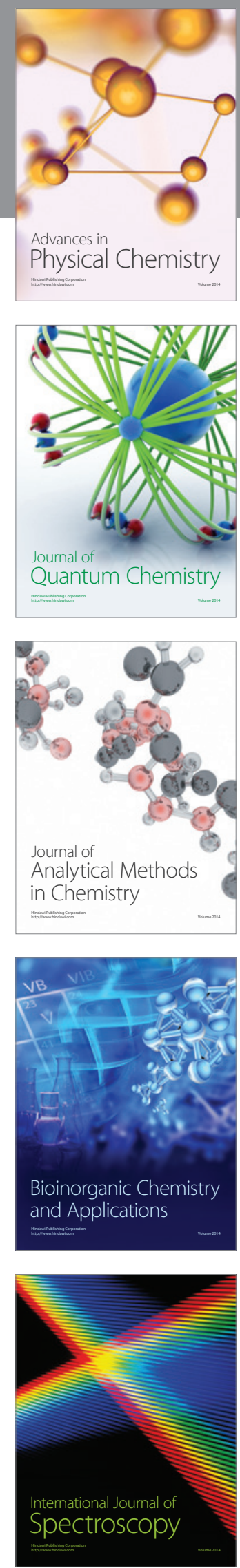